\title{
Las funciones crediticias de las cofradías y los negocios de los mercaderes del Consulado de la ciudad de México, fines del siglo XVIII y principios del siglo XIX
}

\author{
por
}

Guillermina del Valle Pavón

Instituto de Investigaciones Dr. José María Luis Mora

Se analiza la forma en que los mercaderes del Consulado de la ciudad de México se valieron del crédito que otorgaban las cofradias y otras corporaciones religiosas en las últimas décadas del siglo XVIII, cuando el mercado de crédito eclesiástico se dinamizó como consecuencia de la reactivación de la economía de Nueva España. Dichos mercaderes se encontraban entre los principales fundadores de obras pías y fueron los mayores beneficiarios de los fondos piadosos que administraban las corporaciones religiosas, lo que se muestra mediante el examen de cuatro de las hermandades piadosas más acaudaladas.

Palabras Clave: crédito eclesiástico; cofradías; mercaderes; consulados; redes sociales.

En Nueva España la mayor parte de las empresas agropecuarias, mineras y comerciales se sostenían con el crédito que otorgaban las corporaciones religiosas a mediano y largo plazo. Así como en el Antiguo Régimen la cultura católica dictaba ciertas las estrategias de inversión, los diversos cuerpos que formaban parte de la iglesia tuvieron un papel central en la economía del virreinato. Las instituciones eclesiásticas fungían como intermediarios financieros, al recibir los caudales de fieles que establecían fundaciones piadosas, con el propósito de salvar su alma, y prestarlos para que generaran intereses con los que se sostenían las capellanías y obras de caridad que se establecían con dicho fondo. Tal función era desempeñada tanto por los juzgados de capellanías y obras pías -que formaban parte de los obispados-, los conventos y el tribunal de la Inquisición, como por corporaciones laicas como las cofradías, los colegios, hospitales, recogimientos, hospicios y otros institutos que 
desempeñaban funciones sociales. Algunas de estas últimas corporaciones, como las cofradías, se encontraban bajo la jurisdicción de la autoridad eclesiástica, aun cuando manejaran sus fondos con plena autonomía.

La historiografía sobre el Antiguo Régimen colonial de Nueva España se ha centrado en el crédito eclesiástico analizando la naturaleza económica de las instituciones religiosas. Varios autores han mostrado como los fondos que administraban los cuerpos eclesiásticos constituyeron la principal fuente de financiamiento de los principales sectores económicos. Se ha analizado la política religiosa de control de las tasas de interés, el origen de los ingresos de las principales instituciones eclesiásticas, sus estrategias crediticias, los instrumentos de crédito que utilizaron, los prestatarios a los que destinaron sus capitales, los montos prestados, los plazos otorgados y las garantías que respaldaban los préstamos ${ }^{1}$. También se ha examinado la forma en que las corporaciones eclesiásticas contribuyeron al dinamismo de la actividad productiva, en especial durante el siglo XVIII, cuando los propietarios rurales y los grandes comerciantes establecidos en la ciudad de México fueron los principales beneficiarios de los fondos piadosos del arzobispado de México. Asimismo se ha destacado el estrecho vínculo que había entre las élites y las instituciones religiosas, en cuanto al establecimiento de fundaciones piadosas y el otorgamiento de crédito, calificando dicha relación como circular porque gran parte de los fondos crediticios provenía de los miembros de la élite, quienes los recibían a manera de préstamo ${ }^{2}$. En este marco, nos interesa resaltar la forma en que los mercaderes del consulado de la ciudad de México se valieron del crédito eclesiástico para realizar sus negocios, especialmente los que tenían que ver con la cría y contratación de ganado.

En el presente artículo se estudia la forma en que algunos de los mercaderes consulares más destacados controlaron las mesas de gobierno de las cofradías más ricas de la ciudad de México, cuyos fondos se incrementaron en las últimas décadas del siglo XVIII, cuando el crecimiento de la economía, y otros factores, dieron lugar al aumento de la oferta de capitales crediticios. Para ello nos proponemos desarrollar tres objetivos. En primer lugar se analiza la forma en que funcionaba el crédito eclesiástico en el arzobispado de México y las razones por las que los mercaderes de la capital del virreinato se ubicaron entre los principales receptores de los fondos piadosos. En segundo lugar se muestra la forma en que el dinamismo económico que se produjo

${ }^{1}$ Lavrin, 1980; 1985; 1986a; 1986b. Greenow, 1983. García Ayluardo, 1983 y 1986. Bauer, 1986. Wobeser, 1994. Bazarte, 1995. Martínez López-Cano y Valle Pavón, 1998: 13-24.

${ }^{2}$ Lavrin, 1985: 6, 10-28; 1986a: 200-206; 1986b: 257-269. 
en el último tercio del siglo XVIII dio lugar al incremento de los capitales crediticios de las principales cofradías de la ciudad de México y a la fundación de nuevas asociaciones piadosas, cuyas mesas de gobierno estaban integradas, fundamentalmente, por mercaderes del Consulado de la capital. Y, por último, se analiza el modo en que se canalizaron los fondos crediticios de cuatro de las congregaciones piadosas más acaudaladas en los últimos años del siglo XVIII y los primeros del siglo XIX. En esta última parte veremos la importancia que tuvieron las relaciones interpersonales establecidas entre los mercaderes, los grandes productores agropecuarios y la jerarquía eclesiástica en el otorgamiento del crédito por parte de las hermandades.

\section{LOS FONDOS PIADOSOS Y EL OTORGAMIENTO DE CRÉDITO}

Siendo dinero y crédito dos aspectos de un mismo problema, la gran demanda de que era objeto la moneda en Nueva España dio lugar a la generalización de la actividad financiera ${ }^{3}$. El crédito hacía posible la producción y el intercambio de grandes volúmenes de mercancías, y permitía acelerar la velocidad de la circulación del dinero. En Nueva España el financiamiento en metálico siempre estuvo muy restringido. Dada la inexistencia de instituciones financieras formalmente establecidas, el crédito en dinero era otorgado por quienes tenían la posibilidad de concentrarlo: las corporaciones eclesiásticas y los mercaderes. Con el propósito de disponer de circulante para realizar contrataciones, los miembros del Consulado de la ciudad de México se concedían préstamos mutuamente por periodos cortos; recibían crédito a mediano y largo plazo de instituciones religiosas y depósitos de individuos con los que tenían vínculos de confianza ${ }^{4}$. En estos dos últimos casos se imponía un interés del 5\%, que era la tasa máxima permitida por la legislación canónica, de modo que todo contrato que excediera dicha taza se consideraba ilícito y usurario, aun cuando Carlos III había autorizado el cobro de tasas superiores al $5 \%$ en $1763^{5}$. En el caso de los contratos de crédito comercial se imponían

${ }^{3}$ La función del crédito consiste en «independizar la circulación» de los límites del metálico al operar como sustituto del dinero. Hilferding, 1971: 58.

${ }^{4}$ Kicza, 1986: 72-77. Los mercaderes realizaban escrituras de obligación que registraban el adelanto de moneda para adquirir bienes orientales y la venta mercancías para ser restituidas en dinero más adelante. Borchart de Moreno, 1984: 69-72. Asimismo otorgaban préstamos para comerciar en el Pacífico. Valle Pavón, $2010 \mathrm{~b}$.

5 Vázquez de Prada, 1993: 29-31. 
réditos mucho mayores que fluctuaban en función de los riesgos que se corrían y el tiempo de retorno del principal ${ }^{6}$.

Los fondos crediticios que administraban las instituciones religiosas y de caridad provenían de la fundación de obras piadosas que los fieles establecían con el propósito de obtener indulgencias que acortaban la permanencia en el purgatorio ${ }^{7}$. Las obras pías podían instituirse a través de la entrega de capitales o inmuebles, y donando una renta determinada mediante imposición de un gravamen o hipoteca sobre un bien raíz ${ }^{8}$. Los juzgado de testamentos, capellanías y obras pías -que dependían de los obispados- los conventos, las cofradías, y otras corporaciones, laicas y eclesiásticas, en donde se erigían los legados piadosos, prestaban a réditos los caudales y daban en arriendo los inmuebles donados por los creyentes con el fin de generar rentas constantes que se destinaban al sustento de las fundaciones. Las obras pías podían destinarse al beneficio de huérfanas, viudas, presos, dementes y demás menesterosos; o contribuir al sustento de ciertas festividades o de los gastos del culto, como la compra de vino para consagrar, de aceite y cera para iluminar los altares y las imágenes, así como al pago de coros y músicos. Mientras que las capellanías generaban un fondo destinado al sostenimiento de sacerdotes que oficiaban misas y otros rituales por el alma de los fundadores. En Nueva España las capellanías constituían la principal fuente de ingresos de la mayor

6 En una escritura de obligación por 62.049 pesos para adquirir bienes orientales se registró la imposición de un premio del 32\%. Escritura de obligación, México, 19 de abril de 1797, Archivo General de Notarías de la ciudad de México (AGNM), Notario 522 Juan Manuel Pozo, vol. 3496, folios 57-58. Según Tomás Murphy, en la época de las flotas los tratantes prestaban en Veracruz a premio de $12 \%$ a «un riesgo» y $24 \%$ a «dos riesgos», tasas que se redujeron a raíz de la introducción de los navíos sueltos, al pasar de $4 \%$ a $6 \%$ a «un riesgo» y de $12 \%$ a $14 \%$ a «dos riesgos». "Informe reservado de don Tomás Murphy, dirigido al Virrey, sobre el estado que guarda el comercio de la Nueva España (1793)", Florescano y Castillo (comps.), 1975, t. I: 388. En 1807 Abad y Queipo informó que las compras a crédito en Nueva España se negociaban "con pérdida» de un 15\%. Abad y Queipo, 1986: 107. Y según Kicza, en los préstamos comerciales de ultramar, que implicaban grandes riesgos, se fijaba un sobreprecio de $25 \%$, tasa a la que incrementaron un $5 \%$ dos mercaderes que prestaron a un comerciante de Manila en 1805. Kicza, 1986: 84.

7 Los católicos creían que antes de acceder al reino de los cielos, los pecadores arrepentidos tenían que padecer en el purgatorio tormentos similares a los del infierno. Le Goff, 1996: 109-111.

8 Acerca del problema para distinguir entre los censos u obligaciones que gravaban las propiedades con el fin de establecer una fundación piadosa, de aquellos que se establecían para garantizar un préstamo en dinero mediante la hipotecaba de las propiedades, véase Bauer, 1986: 28-43. Lavrin, 1986a: 200-206. Wobeser, 2005: 29-32, 36-40. 
parte del clero secular ${ }^{9}$. Los legados piadosos se basaban en el funcionamiento de una economía financiera que se sustentaba en la fe, así como en el temor al infierno y al purgatorio.

Los fondos piadosos eran objeto de gran demanda por parte de mercaderes, labradores, mineros y otros negociantes. En 1770 se planteaba «es corriente en todo el reino sacar de cuantos juzgados y obras pías hay en él, dinero a depósito irregular...» ${ }^{10} \mathrm{y}$, en los primeros años del siglo XIX se afirmaba que dichos capitales «andan en un continuo giro, sin parar en los juzgados y cofradías, pues cuando se hace una redención, ya hay varios pretendientes [...] tanto que aún hay corredores, que subsisten de andar averiguando el cuerpo y juzgado en que hay algún dinero para imponer» ${ }^{11}$. En estos mercados restringidos, quienes tenían vínculos de parentesco o paisanaje con los prelados, y quienes los estrechaban mediante el establecimiento de fundaciones piadosas y la profesión de sus parientes como religiosas o sacerdotes, tenían mayores posibilidades de obtener a crédito los caudales que administraban las corporaciones religiosas. Los mercaderes se destacaron entre los fundadores de obras pías porque les reportaban indulgencias, así como beneficios sociales, económicos y políticos. Mediante el establecimiento de capellanías dichos actores sociales aseguraban la carrera religiosa de sus familiares, las cuales les brindaban la posibilidad de vivir de manera más o menos desahogada, además de asegurar el vínculo con la administración eclesiástica. Mientras que las obras pías les permitían fomentar las celebraciones y devociones de sus lugares de origen, y socorrer a los peninsulares necesitados, en especial a sus paisanos. Por otra parte, las hijas y hermanas de muchos mercaderes ingresaban como monjas en los conventos más prestigiosos mediante la entrega de las respectivas dotes, las cuales, en algunos casos eran recibidas a réditos por algún miembro de la misma familia.

El mantenimiento de relaciones con los prelados que estaban a cargo del Juzgado de testamentos, capellanías y obras pías, los conventos y otros cuerpos religiosos, brindaban mayores posibilidades para recibir los fondos crediticios de los legados piadosos que administraban ${ }^{12}$. En ocasiones los merca-

9 García, 1983: 53-67. Lavrin, 1986b: 235-278. Bazarte, 1989: 115-118. Luque Alcaide, 1995: 184-189. Wobeser, 1994: 21-33; 2003: 249; 2005.

10 Consulado de México, Año de 1770, diciembre 11, Archivo General de la Nación, México (AGN), Archivo Histórico de Hacienda, leg. 502, exp. 35, folios 10-11. Acerca del depósito irregular véase Wobeser, 1994: 39-50, 83-86, 274-276.

11 "Representación contra la consolidación del ayuntamiento de Valladolid de Michoacán, 8 de octubre de 1805", Sugawara, 1976: 50-58.

12 Acerca del crédito que otorgaron el Juzgado de capellanías y obras pías y otros cuerpos religiosos véanse Lavrin, 1986a: 200-206, 220 y nota 37. Lavrin, 1985. Wobeser, 1994: 56-78, 152. 
deres lograban que el juzgado de capellanías les otorgara a crédito el dinero de las fundaciones que habían sido instituidas por ellos mismos o por sus allegados. Algunas familias acaudaladas reunían varias capellanías a favor de un sacerdote de la misma sangre, y conseguían que los fondos acumulados se destinaran a algún pariente, paisano o socio. Como ejemplo tenemos el caso de los Ycaza que erigieron seis capellanías a nombre del presbítero Mariano de Ycaza, entre 1796 y 1819, cuyos capitales llegaron a sumar 23,500 pesos. En 1796 el Tribunal de capellanías y obras pías otorgó a réditos 3,000 pesos, que constituían el fondo de la primera fundación, al mercader Joseph María de Echave, quien tenía como fiador a su socio Isidro Antonio de Ycaza, padre del capellán propietario. En 1809 ambos sujetos consiguieron que el Juzgado de testamentos les prestara 3,495 pesos de dos capellanías establecidas a favor del presbítero Mariano de Ycaza y en 1829 los 23,500 pesos que sumaban las seis capellanías que había concentrado el mismo presbítero ${ }^{13}$. En esta forma el establecimiento de capellanías y obras pías permitía asegurar la disposición de capitales crediticios para invertir en los negocios de los propios fundadores.

Los mercaderes consulares obtuvieron gran parte del crédito que otorgaban las corporaciones religiosas por varias razones. Primera, porque poseían propiedades raíces que hipotecaban en garantía de los préstamos ${ }^{14}$. Segunda, porque tenían vínculos de confianza con individuos de reconocida solvencia que fungían como sus fiadores. Tercera, por las relaciones interpersonales que tenían con los prelados que estaban a cargo de cuerpos religiosos que administraban los fondos piadosos, circunstancia que les daba acceso a información privilegiada, como la referente a la disposición de caudales crediticios. Dichos vínculos también favorecían sus nombramientos como síndicos o tesoreros de los conventos, hospitales, recogimientos y otras instituciones de caridad. Y cuarta, por la participación central que tenian en las juntas directivas de las cofradías laicas más acaudaladas. La influencia que tenían los mercaderes en los conventos, las cofradías y otros cuerpos religiosos y de beneficencia se pone de manifiesto en los numerosos depósitos a réditos que otorgaron al Tribunal del consulado cuando negoció empréstitos en nombre de la corona para contribuir a financiar las guerras de fines del siglo XVIII ${ }^{15}$.

13 México, 24 de mayo de 1796, AGN, Capellanías, vol. 97, exp. 1004 y 1026. AGN, Bienes Nacionales, vol. 1124, exp. 14.

14 Sobre las propiedades que concentraban los mercaderes en el periodo 1759-1778, véase Borchart de Moreno, 1984: 134-169 y 178-208. Para fines del siglo XVIII y principios del XIX, Kicza, 1986: 34-43, 184.

15 Una parte sustancial de dichos préstamos provenía del Juzgado de capellanías y obras pías, de conventos, cofradías, oratorios y colegios. Valle Pavón, 2012. 
La oferta de crédito dinerario en el arzobispado de México presentó una notable expansión como consecuencia del auge de la producción minera, que se incrementó de manera notable poco después de la segunda mitad del siglo XVIII ${ }^{16}$. Uno de los primeros indicadores del dinamismo que presentaba el incipiente mercado de capitales fue el mandato del visitador José de Gálvez de imponer el cobro de alcabala al depósito irregular, a fines de 1769. Esta orden fue derogada al cabo de unos meses por el virrey marqués de Croix, en atención a las representaciones elaboradas por el arzobispo, el cabildo eclesiástico y el tribunal del Consulado de México en contra de dicha medida ${ }^{17}$. La economía virreinal también se activó como consecuencia de la apertura comercial en el Pacífico, establecida en $1774{ }^{18}$. En este mismo año, cuando se propuso la creación del banco de avío para la minería, se sugirió utilizar para ello «algunos millones de pesos [...]» que estaban «parados en las arcas de eclesiásticos por falta de quien los reciba sobre buenos seguros» ${ }^{19}$. Unos años después el real Fisco, que administraba los fondos de la Inquisición, declaró que «[...] comunidades, tribunales y archicofradías tienen dinero de sobra para dar a cuantos necesitados llegan a pedir» ${ }^{20}$. El aumento de la oferta de crédito también puede constatarse por el incremento que presentaron los fondos de las cofradías más acaudaladas y la creación de un importante número de nuevas hermandades piadosas, aspectos que analizaremos más adelante.

En el desarrollo de los mercados crediticios de la capital del virreinato también influyó la modificación de los patrones de inversión de los mercaderes de México que produjo el establecimiento del libre cambio a partir del

16 Acerca del aumento de la producción minera véase Sánchez Santiró, 2002: 129-132. Los fondos piadosos también contribuyeron al fomento de la minería, en 1770 el Consulado de México aseveraba que «Sólo del Convento de Santa Clara de Querétaro gira en la minería y comercio de Guanajuato 300.000 pesos para arriba». Consulado de México, 11 de diciembre de 1770, AGN, Archivo Histórico de Hacienda, leg. 502, exp. 35.

17 Consulado de México, 11 de diciembre de 1770, AGN, Archivo Histórico de Hacienda, leg. 502, exp. 35. Otro indicador del aumento de la disponibilidad de dinero crediticio en el arzobispado de México fue la propuesta de crear el Real Monte de piedad para socorrer a los menesterosos, presentada a la corona por el minero Pedro Romero de Terreros en 1767, la cual se materializó cuando Carlos III expidió la real cédula para su fundación, en junio de 1774. Couturier, 1975: 13-30.

18 Valle Pavón, 2010b. Lavrin ubicó dicha expansión a partir de 1789, año en que se hizo extensivo el librecambio a Nueva España. Lavrin, 1985: 7, 8 y 10-26. Sobre el dinamismo que presentó la actividad crediticia a fines del siglo XVIII también puede verse Wobeser, 1994: $115-117,125,160,170,251$ y 252.

19 Moreno de los Arcos, 1978: 125-126

20 Citado en Wobeser, 1990: 865. 
periodo 1779-1789. La reducción de precios de los bienes europeos ocasionada por el abasto continuo condujo a los tratantes del interior a abandonar la costosa intermediación de los mexicanos y aumentar su participación en los mercados locales y regionales ${ }^{21}$. Para mantener el control del circulante y el consiguiente dominio sobre los intercambios, los miembros del Consulado de México invirtieron directamente en la explotación argentífera, incrementaron su participación en la producción y comercio de los bienes agropecuarios más demandados, dentro y fuera del virreinato, y recurrieron en mayor medida al crédito y a los medios de pago alternativos, así como al otorgamiento de préstamos en metálico ${ }^{22}$. Presumimos que el dinamismo económico que se produjo como consecuencia de los cambios mencionados dio lugar a la creación de mayores excedentes, parte de los cuales se destinaron al establecimiento de capellanías y fundaciones piadosas. Fue así como las instituciones religiosas y caritativas elevaron la oferta de los fondos crediticios.

\section{El papel de los mercaderes en las cofradías de la ciudad de MéXico}

En el Antiguo Régimen había un profundo entrelazamiento entre las prácticas de la cultura católica y la actividad financiera, fenómeno que se pone de manifiesto a través del estudio de las actividades de las asociaciones piadosas. A continuación se analiza el papel crediticio que desempeñaron las principales cofradías seculares de la ciudad de México a partir del último tercio del siglo XVIII, cuando los mercaderes consulares se encontraban a cargo las mismas.

Las hermandades piadosas operaban como entidades autónomas, aun cuando estaban subordinadas a la autoridad del monarca y de la diócesis ${ }^{23}$. Una vez que el arzobispo y el Consejo de Indias aprobaban la erección y las constitu-

21 Veracruz desplazó progresivamente a la capital como principal centro de distribución de los bienes europeos. Florescano y Castillo (comps.), 1976, t. I: 204-205.

22 Brading, 1975: 160-167, 246-251, 261-263 y 275-281. Kicza, 1986: 102-107. Pérez Herrero, 1988: 209-215. Valle Pavón, 2003: 272-282; 2010b: 54-47.

23 En la Recopilación de las leyes de Indias de 1681 se estableció que las hermandades debían contar con licencia del monarca y el prelado eclesiástico, sus estatutos debían ser confirmados por el Consejo de Indias y en sus cabildos debía estar presente un ministro real, así como el prelado de la casa donde se reunían, Ley xxv, título 4 , libro $1^{\circ}$, tomo I, fol. 20 (Manzano Manzano, 1973). En la reforma de las cofradías que emprendió el Consejo de Indias a partir de 1776 se insistió sobre la presencia de los jueces reales en las juntas de las cofradías. Carbajal López, 2012: 98. 
ciones de las cofradías ${ }^{24}$, éstas se regían por una junta de gobierno elegida entre sus miembros más influyentes, piadosos y caritativos. Las congregaciones que obtenían la anuencia del monarca quedaban bajo su jurisdicción y la del virrey, circunstancia que las eximía de la competencia de los tribunales civiles y eclesiásticos. Por este motivo, las cofradías más ricas pusieron especial empeño en obtener licencia real ${ }^{25}$. El otorgamiento de crédito a través de las hermandades resultó idóneo para los mercaderes porque les brindaban un marco institucional y comunitario que reforzaba las relaciones de confianza en que se basaban sus redes de negocios. A través de las cofradías los mercaderes obtenían indulgencias, fomentaban el culto a las devociones y prácticas religiosas de sus lugares de origen, y socorrían a sus paisanos y a otros necesitados ${ }^{26}$.

Poco después de la segunda mitad del siglo XVIII, al tiempo que se reactivaba la economía de Nueva España, se elevaron de manera creciente los fondos crediticios de las hermandades piadosas constituidas y administradas por destacados miembros del Consulado, que, según vimos, se destacaban como fundadores de obras pías. La Cofradía de Nuestra Señora de Aránzazu, que agrupaba a los sujetos originarios y procedentes de Navarra, Vizcaya, Allava y Guipúzcoa ${ }^{27}$, entre los que predominaban los mercaderes, a partir de la década de 1760 incrementó de manera progresiva los fondos prestables ${ }^{28}$. Lo mismo sucedió en la Archicofradía del Santísimo Sacramento y Caridad y en la Archicofradía de Nuestra Señora del Rosario, cuyas mesas directivas eran manejadas por distinguidos miembros del Consulado ${ }^{29}$.

24 Las reformas establecidas a partir de la década de 1770 mandaban a las cofradías regularizar su situación de acuerdo con lo establecido por la Recopilación de las leyes de Indias de 1681 (Manzano Manzano, 1973), de aquí que las constituciones de las cofradías establecidas y de nueva creación debieran ser autorizadas por el Consejo de Indias. García Ayluardo, 2010: 267-268. Carbajal López, 2012: 83-87.

25 Lavrin, 1980: 567. Wobeser, 1994: 94-95. García Ayluardo, 2007: 109-118. Acerca de los esfuerzos de la Cofradía de Aránzazu para conseguir independencia del arzobispado, véanse García Ayluardo, 1983: 55 y Luque Alcaide, 1995: 169, 214, 215 y 219.

26 Bazarte, 1989: 89-114 y 156-161; 1990: 57-60. Luque Alcaide, 1995: 171-172. Acerca del significado de las prácticas religiosas y comunitarias de las cofradías véanse Lavrin, 1980: 568 y García Ayluardo, 2007: 92-96.

27 Fundada en 1681, la cofradía de Aránzazu había conseguido autonomía jurídica de los tribunales civiles y eclesiásticos. La mayor parte de los rectores de Aránzazu fueron miembros del Consulado. Luque Alcaide, 1995: 42-55, 125-127, 143-167, 213-222 y 339-343.

28 Además se fundaron cofradías de Aránzazu en Guadalajara, en 1775, y en Puebla, en 1788. Luque Alcaide, 1995: 41, 194, 195 y anexo VI: 347-353.

29 Lavrin, 1986b: 258, 262-263 y 265- 266. La Archicofradía del Santísimo elevó su fondo, en gran medida, porque a raíz de la expulsión de los Jesuitas, le transfirieron los caudales que administraba la Congregación de El Salvador. Bazarte, 1989: 94-101 y 158-159. 
En la década de los setentas, los mercaderes de México crearon nuevas hermandades piadosas en alianza con otros personajes pertenecientes a la élite, la alta jerarquía eclesiástica y la administración virreinal. Los grandes comerciantes provenientes de las montañas de Santander, en 1775 fundaron la Congregación del Santísimo Cristo de Burgos $^{30}$. Estos mercaderes y los de origen vizcaíno constituían las dos facciones en que se habían dividido los miembros del Consulado de México, desde fines del siglo XVII, para elegir al prior y los cónsules de su tribunal, quienes también los representaban. En la década de 1740 ambos grupos se habían institucionalizado como partidos ${ }^{31}$. En 1774 el arzobispo, dos prelados de la catedral y ocho miembros del consulado, cuatro vizcaínos y cuatro montañeses, habían erigido la Congregación de Niños Expósitos de la Cuna $^{32}$. En los decenios de 1780 y 1790 se constituyeron nuevas hermandades en las que los mercaderes consulares tuvieron una participación central ${ }^{33}$. Entre estas se destacan la Congregación de Nuestra Señora de Covadonga, constituida en 1785 por prominentes individuos naturales y originarios de Asturias que obtuvieron aprobación real para su hermandad ${ }^{34}$, y la Cofradía del Alumbrado y Vela Perpetua del Santísimo Sacramento, fundada en 1793 por un puñado de nobles terratenientes y mercaderes criadores de ganado, entre los que se destacan el Mariscal de Castilla, el marqués del Valle de la Colina y el conde de la Cortina.

30 Dicha Congregación se estableció en la capilla del Convento de San Francisco, en donde hasta entonces había estado la Cofradía del Santísimo Patriarca San José, en la que se asociaban carpinteros montañeses y los diputados de su mesa de gobierno eran prominentes mercaderes y vecinos montañeses de la ciudad de México. Esta hermandad había decaído por falta de recursos. Archivo Histórico de la Secretaría de Salubridad (AHSS), fondo cofradías, Sección Cofradía del Santísimo Cristo de Burgos, serie Libros, 7, 1775. Salazar, 1990: 9-16, 60 y 61.

31 Valle Pavón, 2003: 260-163; 2007: 973-986.

32 La mesa de la Congregación de la Casa de la Caridad de Niños Expósitos dan poder a su tesorero para que administre sus bienes, México, 26 de febrero de 1774, AGNM, notario 350, Diego Jacinto de León, vol. 2302, folios 91-92v.

33 En 1782 se constituyó la Cofradía de Nuestra Señora de los Siete Dolores y Soledad en cuya mesa directiva colaboraban mercaderes. Razón que producen el Rector y vocales que componen la Mesa de la Cofradía de Nuestra Señora de los siete Dolores, Soledad y Santisimo Sacramento, de la Parroquia de la Soledad y Santa Cruz de México en 16 de octubre de 1805, AGN, Cofradías, vol. 6, exp. 4, folios 411-414.

${ }^{34}$ Los asturianos celebraban en la ciudad de México la fiesta de Nuestra Señora de Covadonga desde 1732-1733. Se sabe que en septiembre de 1780 un grupo de mercaderes de dicha «nación»solicitaron al virrey Martín de Mayorga autorización para establecer una congregación como la que sus paisanos tenían en Madrid, y obtuvieron la aprobación del monarca en 1784. Fernández García, 1997: 777-780. 
Como vimos, las asociaciones piadosas eran gobernadas por su mesa directiva, la cual se encargaba, fundamentalmente, de organizar las ceremonias religiosas, aceptar nuevos miembros y administrar sus fondos, todo de acuerdo con sus respectivas constituciones. El número de miembros de las juntas de gobierno variaba, aun cuando la mayoría estaban constituidas por doce individuos, como los doce apóstoles de Jesucristo ${ }^{35}$. Los consejos actuaban de manera conjunta y tomaban las decisiones por mayoría de votos ${ }^{36}$. Gran parte de los miembros de las juntas de gobierno de las cofradías más acaudaladas eran mercaderes del Consulado de México, entre los que se distinguieron los más prominentes porque participaban en los consejos de dos y tres hermandades de manera simultánea ${ }^{37}$.

La conformación de las mesas de gobierno de las cofradías por parientes, paisanos y compadres que formaban parte de las mismas redes de negocios los llevaba a profesarse una enorme confianza mutua. Como ejemplo tenemos a la Congregación del Santísimo Cristo de Burgos, cuyos fundadores establecieron que en caso de que se disolviera, sus bienes se traspasarían a la Archicofradía del Santísimo Sacramento ${ }^{38}$. Los mercaderes que no eran miembros de los consejos de las hermandades también depositaron su confianza en dichos órganos. José Gómez de la Cortina, en su testamento dio poder al rector y los diputados de la Congregación del Santo Cristo de Burgos, que habían sido nombrados de manera perpetua, para que cuidaran el cumplimiento de las condiciones del mayorazgo que instituyó a nombre de su sobrino ${ }^{39}$. Mientras que Joaquín Dongo, quien legó la mayor parte de su fortuna a diversas obras pías y capellanías, nombró a la Archicofradía del Espíritu Santo como su única albacea ${ }^{40}$.

El conocimiento de los fundadores de las congregaciones y de los miembros de sus mesas de gobierno permite identificar los vínculos interpersonales que tenían los mercaderes que formaban parte de las mismas. La Congrega-

35 Gazeta de México, AGN, t. IV, no 24, fol. 225. Lavrin, 1986b: 260. Luque Alcaide, 1995: 38, 328-329, 333-334. García Ayluardo, 2007: 93-94.

36 Bazarte, 1989: 216-218. Luque Alcaide, 1995: 213.

37 AGN, Indiferente virreinal, Minería, vol. 548, exp. 2; Templos y Conventos 108, vol. 9, exp. 7; Cofradías, vol. 6, exp. 4, folios 362-414 y exp. 7, folios 499-515. AGNM, notario 591 Felipe Romo de Vera, vol. 4035; notario 350 Diego Jacinto de León, vol. 2302. Salazar, 1990: 16-17, 20 y 139. Iguíniz, 1951: 39-40 y 204-205. Bazarte, 1989: 184. Lavrin, 1986b: 258. Luque Alcaide, 1995: 342-343. García Ayluardo, 1983: 120.

38 Bazarte, 1989: 159.

39 Escritura de fundación del mayorazgo Gómez de la Cortina, México, 19 de septiembre de 1778, AGNM, Notario 350 Diego Jacinto de León, 1778.

40 Castillo Múzquiz, 2009: 240. 
ción de Nuestra Señora de Covadonga, que integraba a los oriundos de Asturias, constituye un buen ejemplo de las personalidades que podrían asociarse para constituir la hermandad de una nación. Entre los fundadores se encontraban individuos pertenecientes a las principales esferas de poder del virreinato: el Inquisidor decano del Santo Oficio y canónigo de la iglesia Metropolitana, Juan de Mier y Villar; dos de los más altos funcionarios de la administración virreinal: Ramón Posada, caballero de Carlos Tercero que era fiscal de la real Hacienda, y Cosme de Mier y Trespalacios, alcalde de la real Audiencia que estaba casado con la hija del mercader Francisco Ignacio de Yraeta, quien fue cónsul del tribunal mercantil en 1789-1790; el canónigo de la iglesia Metropolitana, Provisor y Vicario General del Arzobispado, José Ruiz de Conejares; y el mercader Pedro Alonso de Alles, tesorero de la Bula de la Santa Cruzada, que había sido cónsul del tribunal mercantil en 17751776, era caballero de Calatraba y en 1792 sería nombrado marqués de Santa Cruz de Ynguanzo. El resto eran prelados de "rancia cuna" de la Inquisición, la catedral Metropolitana y el Arzobispado ${ }^{41}$. Como puede verse en el cuadro 1 la primera mesa de gobierno de la Congregación de Nuestra Señora de Covadonga estaba presidida por el mismo Pedro Alonso de Alles, el tesorero era Joaquín Alonso de Alles, el Primer Secretario y contador el bachiller José Antonio de Noriega ${ }^{42}$. y seis diputados, dos de los cuales eran mercaderes consulares. Varios de ellos eran parientes, como se deduce de la repetición de sus apellidos ${ }^{43}$.

\section{Redes crediticias en las cofradías más aCAudaladas de MéXico}

Aun cuando las cofradías estaban dedicadas fundamentalmente al culto divino y la caridad, entre las principales funciones de sus mesas directivas se encontraba la administración de sus propios capitales ${ }^{44} \mathrm{y}$ de los que pertenecían a los legados piadosos que les habían encomendado. Los consejos se

41 Fernández García, 1997, vol. II: 777-796.

42 Ibidem: 791.

43 Gazeta de México, AGN, t. IV, nº 24, fol. 225.

44 El patrimonio de las cofradías estaba integrado fundamentalmente por las cuotas que debían aportar los miembros de sus mesas de gobierno, la cuales eran complementadas por las aportaciones voluntarias de los cofrades. Algunas hermandades contaban con patronatos que habían legado ciertos miembros. Lavrin, 1986b: 259. Luque Alcaide, 1995: 171, 329; 1990: 57-60. El Consejo de Indias corrigió las constituciones de la Cofradía del Santo Cristo de Burgos en 1775, al establecer que las limosnas de acceso debían ser voluntarias. Carbajal López, 2012: 93-95. 


\section{Cuadro 1. Congregación de Nuestra Señora de Covadonga, MESA DE GOBIERNO, 1790}

\begin{tabular}{|l|l|l|}
\hline \multicolumn{1}{|c|}{ Nombres } & \multicolumn{1}{c|}{ Cargos } & \multicolumn{1}{c|}{ Institución } \\
\hline Alonso de Alles, Pedro & Prefecto & Consulado \\
\hline Alonso de Alles, Joaquín & Tesorero & Consulado \\
\hline Bulnes Villar, Juan & Diputado & $\begin{array}{l}\text { Pariente de miembro } \\
\text { del Consulado }\end{array}$ \\
\hline Covián de los Ríos, Pascual & Diputado & \\
\hline Fernández de Muria, Santos & Diputado & \\
\hline González Cadamo, Juan & Portero & \\
\hline González de Noriega, Lorenzo & Diputado & \\
\hline Mier y Noriega, Servando; doctor & Celador del culto & \\
\hline Noriega, José Antonio de; bachiller & $\begin{array}{l}\text { 1er. secretario y } \\
\text { contador }\end{array}$ & \\
\hline Martínez, Pablo; capitán & Diputado & Consulado \\
\hline Samohano y Alonso, Simón de & $\begin{array}{l}\text { 2do. secretario y } \\
\text { archivero }\end{array}$ & Diputado \\
\hline Valle, Manuel del; subteniente & . & \\
\hline
\end{tabular}

Fuente: Gazeta de México, IV/24, martes 21 de diciembre de 1790: 225.

encargaban de imponer dichos fondos a réditos y de prorrogar los préstamos a quienes saldaban los intereses con puntualidad; cuando se restituían los caudales buscaban nuevos depositarios; subrogaban a los fiadores que fallecían, se arruinaban o se mudaban y, en caso de quiebra, seguían los pleitos que involucraban a las propiedades gravadas ${ }^{45}$. Como veremos a continuación, el acceso al crédito que otorgaban las cofradías se basaba en relaciones interpersonales, de aquí que los mercaderes y los sujetos que tenían vínculos con los miembros de las mesas de gobierno tuvieran mayores posibilidades de ser favorecidos.

Con el propósito de conocer las estrategias crediticias de las sociedades piadosas de la ciudad de México, examinamos los préstamos otorgados por cuatro de las hermandades más acaudaladas, que estaban vigentes en octubre de 1805. Para ello recurrimos a los informes que presentaron a la Junta de Consolidación de vales reales la Archicofradías del Santísimo Sacramento y Caridad, la Congregación del Santo Cristo de Burgos y la Cofradía de Nues-

45 García Ayluardo, 1983: 60-63; 1986: 44-48. Bazarte, 1989: 115-117 y 156-161. Luque Alcaide, 1995: 121-132, 184-189. Wobeser, 1994 y 2005. 
tra Señora de Aránzazu ${ }^{46}$, documentos en los que se registraron los contratos de crédito cuyos plazos habían vencido antes de la publicación del real decreto $^{47}$. En el caso de la cofradía de Aránzazu además contamos con algunos ejemplos de préstamos otorgados unos años antes de 1805. Asimismo se examinan los préstamos concedidos por la Archicofradía de Nuestra Señora del Rosario, con base en la información proporcionada por Asunción Lavrin ${ }^{48}$ y diversos documentos de archivo.

La Archicofradía del Santísimo Sacramento y Caridad destinó gran parte de los capitales que administraba a productores agrícolas y ganaderos que dieron en garantía sus propiedades rurales, lo cual puede verse en detalle en el cuadro 2. Entre los productores agropecuarios se destacan dos latifundistas que ostentaban títulos de nobleza, el marqués de San Miguel de Aguayo y la marquesa de San Francisco, María Micaela Romero de Terreros, primogénita del conde de Regla. Este, poco antes de morir, había solicitado un préstamo por 500.000 pesos para adquirir la hacienda de Tetillas, en Zacatecas, que había sido propiedad de la Compañía de Jesús. Como la Archicofradía sólo podía prestarle 200.000 pesos, su mesa se encargó de negociar un crédito mancomunado con otros ocho prestamistas $^{49}$. De los demás labradores que recibieron dinero a réditos dos eran mercaderes consulares y uno más pariente de otro miembro del cuerpo mercantil. Entre los prestatarios que no hipotecaron inmuebles, se encontraba un regidor del ayuntamiento de México y el hermano del conde de Medina y Torres, que dio en garantía el valor del oficio de escribano de la real Audiencia. Únicamente dos prestatarios fueron respaldados por fiadores, un vecino de San Ángel, pariente de un elemento del Consulado de México, y un miembro del consulado de Veracruz que tuvo como avales a dos miembros del cuerpo mercantil de la ciudad de México, con quienes, muy probablemente, realizaba negocios.

Siendo el sostenimiento de las obras pías el principal objetivo de los créditos que otorgaban las cofradías, el dinero se mantenía en manos de los acreedores siempre que satisficieran el pago de réditos con puntualidad ${ }^{50}$. Esto explica que algunos de los préstamos que otorgó la archicofradía dataran de los años treinta, cincuenta, sesenta, setenta, ochenta y noventa. Los préstamos que se habían otorgado más recientemente eran los que se habían garantizado con fiadores a plazos que variaban entre los dos y los cinco años.

\footnotetext{
46 Los préstamos otorgados por la Cofradía de Aránzazu y la Congregación del Cristo de Burgos fueron examinados y publicados en Wobeser, 1994: 97-100 y 232-235.

47 Luque Alcaide, 1995: 199-202 y 352, 353.

48 Lavrin, 1986b: 257-276.

49 Wobeser, 1994: 99-100.

50 Ibidem: 38-50.
} 


\section{Cuadro 2. Informe de la archicofradía del Santísimo Sacramento Y CARIDAD SOBRE OBRA PÍAS Y CAPELLANÍAS, 1805}

\begin{tabular}{|c|c|c|c|}
\hline Prestatarios & Pesos & Año & Hipoteca o fiador \\
\hline \multicolumn{4}{|l|}{ Empresarios agropecuarios } \\
\hline $\begin{array}{l}\text { Aguayo, marqués de San Miguel } \\
\text { de y conde de San Pedro del } \\
\text { Álamo }\end{array}$ & 40000 & 1752 & $\begin{array}{l}\text { Haciendas, minas y casa en } \\
\text { México }\end{array}$ \\
\hline Cobián de los Ríos, José Pascual & 6000 & & $\begin{array}{l}\text { Hacienda Tepetates (en } \\
\text { litigio) }\end{array}$ \\
\hline $\begin{array}{l}\text { Gil, Antonio, en } 805 \text { reconoció el } \\
\text { gravamen de Tamariz Paz y Lugo }\end{array}$ & 11000 & 1732 & Hacienda en Chalco \\
\hline Fernández de Peredo, Juan & 6000 & 1790 & Hacienda en Tianguistengo \\
\hline Oteyza y Vertiz, Juan José & 3000 & & Haciendas en Toluca \\
\hline Quintana, María & 6200 & & $\begin{array}{l}\text { Hacienda en concurso de } \\
\text { acreedores }\end{array}$ \\
\hline $\begin{array}{l}\text { Romero de Terreros y Trebuesto, } \\
\text { María Micaela Gregoria }\end{array}$ & 200000 & 1782 & $\begin{array}{l}\text { Hacienda Tetillas y bienes } \\
\text { no vinculados del conde de } \\
\text { Regla }\end{array}$ \\
\hline $\begin{array}{l}\text { Sánchez de Tagle, Francisco Anto- } \\
\text { nio, sus herederos }\end{array}$ & 12000 & 1760 & Hacienda en Coyoacán \\
\hline Sánchez, Nicolás & 1500 & 1780 & Haciendas en Huichapan \\
\hline $\begin{array}{l}\text { Valparaíso, condesa de San Mateo } \\
\text { de }\end{array}$ & 40000 & 1804 & Haciendas \\
\hline Subtotal & 325700 & & \\
\hline \multicolumn{4}{|c|}{ Funcionarios, mercaderes, convento } \\
\hline $\begin{array}{l}\text { Barroeta, Martín de San Juan, } \\
\text { vecino del pueblo de San Ángel }\end{array}$ & 3384 & 1803 & $\begin{array}{l}\text { Manuel de la Concha y } \\
\text { Manuel Moncada }\end{array}$ \\
\hline $\begin{array}{l}\text { Convento Hospital del Espíritu } \\
\text { Santo }\end{array}$ & 40000 & 1770 & Casas \\
\hline $\begin{array}{l}\text { Cuevas Monroy Guerrero } \\
\text { Luyando, Manuel, regidor, y } \\
\text { Francisco Maniau y Torquemada }\end{array}$ & 10000 & 1805 & No se indica \\
\hline $\begin{array}{l}\text { Herrero, Matías (el Juzgado de } \\
\text { capellanías otorgó el depósito) }\end{array}$ & 5315 & & Casas \\
\hline $\begin{array}{l}\text { Medina, Joaquín Benito de, } \\
\text { hermano del conde de Medina y } \\
\text { Torres }\end{array}$ & 9000 & 1780 & $\begin{array}{l}\text { Valor del oficio escribano } \\
\text { de la Audiencia }\end{array}$ \\
\hline $\begin{array}{l}\text { Pavón y Muñoz, José Ignacio, del } \\
\text { Consulado de Veracruz }\end{array}$ & 22000 & 1804 & $\begin{array}{l}\text { Manuel García Herreros e } \\
\text { Ignacio Ampaneda }\end{array}$ \\
\hline Valenzuela, Jerónimo de & 5800 & 1805 & No se indica \\
\hline Subtotal & 95499 & & \\
\hline
\end{tabular}




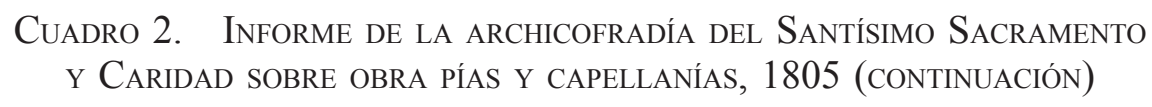

\begin{tabular}{|c|c|c|c|}
\hline \multicolumn{4}{|c|}{ Tribunales del Consulado y Minería } \\
\hline Consulado de México & 60000 & 1793 & $\begin{array}{l}\text { Primer } 5 \text { al millar avería } \\
\text { extraordinaria }\end{array}$ \\
\hline Consulado de México & 67000 & 1794 & $\begin{array}{l}\text { Segundo } 5 \text { al millar avería } \\
\text { extraordinaria }\end{array}$ \\
\hline Consulado de México & 4000 & 1795 & Renta de tabaco \\
\hline Consulado de México & 14000 & 1795 & Renta de tabaco \\
\hline Consulado de México & 50000 & 1798 & Renta de tabaco \\
\hline Consulado de México & 112000 & 1801 & Renta de tabaco \\
\hline Tribunal de Minería & 25000 & 1801 & Renta de tabaco \\
\hline Consulado de Veracruz & 70000 & 1804 & Peaje y avería consular \\
\hline Subtotal & 402000 & & \\
\hline
\end{tabular}

Fuente: Razón de los caudales de Capellanías y Obras Pías de que es Patrona la muy ilustrísima Archicofradía del Santísimo Sacramento y Caridad.... México, 17 de octubre de 1805, Archivo General de la Nación, México (AGN), Cofradías, vol. 6, exp. 4, folios 362-414. Valle Pavón, 1997: 288-289.

El rubro de inversión más importante de la Archicofradía del Santísimo Sacramento fueron los depósitos que colocó a premio en los tribunales del Consulado de México y de Minería, que habían operado como intermediarios financieros de la real Hacienda con el propósito de reunir varios empréstitos millonarios solicitados por la corona para financiar sus guerras imperiales ${ }^{51}$. Uno de los depósitos concedidos al Tribunal mercantil había sido subrogado a la condesa de San Mateo de Valparaíso, criadora y tratante de carneros que poseía una gran hacienda en San Miguel el Grande ${ }^{52}$. La archicofradía había otorgado al Consulado de Veracruz un crédito a cinco años por la enorme suma de 70.000 pesos, para la construcción del camino carretero que enlazaba dicho puerto con la villa de Jalapa, mediante la hipoteca de los productos del peaje que se impuso a la circulación en dicha vía y los de la avería que cobraba el Consulado de Veracruz ${ }^{53}$. Los préstamos por sumas tan elevadas se efectuaban mediante la reunión de los fondos de numerosas fundaciones. La mayor parte de estos últimos préstamos se habían conferido en la década

51 Valle Pavón, 1997: 288-289 y 291.

52 Sánchez de Tagle, 1982: 59, 84.

53 Razón de los caudales de Capellanías y Obras Pías de que es Patrona la muy ilustrísima Archicofradía del Santísimo Sacramento y Caridad... México 17 de Octubre de 1805, AGN, Cofradías, vol. 6, exp. 4, folios 362-414. Valle Pavón, 1997: 288- 289. 
de 1790 y los primeros años de la de 1800. Los depósitos que se colocaron en los tribunales del Consulado y Minería para financiar las guerras de la corona se otorgaron de manera indefinida, por lo que carecían de fecha de vencimiento.

La Archicofradía de Nuestra Señora del Rosario canalizó la mayor parte de los fondos que se encontraban bajo su custodia a empresarios agropecuarios mediante la hipoteca de sus propiedades rústicas. Como puede verse en el cuadro 3, esta asociación piadosa también participó en el préstamo mancomunado que se otorgó a María Micaela Romero de Terreros, la hija del conde de Regla $^{54}$. Asimismo concedió dinero a premio a José Sánchez de Espinoza, hijo conde de Santa María de Guadalupe del Peñasco, y a José Germán del Valle, ambos productores de pulque y granos en Zempoala y Otumba; al mercader Gabriel de Yermo, dedicado al abasto de carne a la capital y dueño de ingenios en Cuernavaca, y a Diego de Rul, criador de ganado en Zacatecas y Aguascalientes. La cofradía otorgó préstamos a parientes de individuos que formaban parte de su mesa de gobierno, como la condesa de Rábago, propietaria de haciendas Coyoacán, Chalco, Salamanca, Celaya, Guanajuato y Nuevo Santander, y al marqués del Apartado, Francisco Fagoaga, que era un destacado minero y productor agropecuario, así como a José Ignacio Belle Cisneros, pariente del marqués quien fue su fiador. El marqués y su hermano, Juan Bautista Fagoaga, en 1792 habían formado una sociedad con los hermanos Francisco, Manuel Ignacio y José Ignacio Belle Cisneros para financiar la producción de la hacienda que éstos poseían en Zinacantepec, al occidente de Toluca. En 1798, cuando se venció el plazo de la deuda contraída por José Ignacio Belle Cisneros en la Archicofradía, el marqués del Apartado tuvo que saldarla $^{55}$. La archicofradía del Rosario también colocó caudales en el Consulado de México, para los empréstitos que negoció en nombre del Rey con el fin de apoyar las guerras imperiales. Asimismo depósito dinero a réditos en la real Hacienda y en el ayuntamiento de la ciudad de México ${ }^{56}$.

La Cofradía de Nuestra Señora de Aránzazu otorgó la mayoría de los fondos piadosos que administraba a negociantes vizcaínos de la ciudad de México y, en menor medida a los del interior del virreinato. Asimismo concedió préstamos a individuos que no pertenecían a dicha nación, entre los cuales identificamos a algunos mercaderes montañeses. Como puede verse en el cuadro 4 la congregación otorgaba préstamos con garantía de uno, dos, tres y hasta cinco fiadores. En esta forma aseguraba el principal ante la posible

\footnotetext{
54 Wobeser, 1994: 99-100.

55 Pérez, 2003: 123-124. Lavrin, 1986b: 259-276.

56 Lavrin, 1986b: 259-276. Valle Pavón, 1997: 289 y 291.
} 
Cuadro 3. Préstamos otorgados por la archicofradía de Nuestra SEÑORA DEL ROSARIO CON FONDOS DE OBRAS PÍAS Y CAPELLANÍAS

\begin{tabular}{|c|c|c|c|c|}
\hline Prestatarios & Pesos & Entrega & Vigente & Hipoteca o fiadores \\
\hline Barreda, Francisco & 12000 & - & 1805 & - \\
\hline $\begin{array}{l}\text { Beye de Cisneros, José } \\
\text { Ignacio }\end{array}$ & 20000 & 1785 & 1796 & $\begin{array}{l}\text { Francisco de Fagoaga, } \\
\text { marqués del Apartado }\end{array}$ \\
\hline $\begin{array}{l}\text { Fagoaga, Francisco de, } \\
\text { marqués del Apartado }\end{array}$ & 30000 & 1786 & 1796 & $\begin{array}{l}1799 \text { Juan Bautista } \\
\text { Fagoaga, queda como } \\
\text { prestatario }\end{array}$ \\
\hline Herrera, José Miguel de & 30000 & - & 1786 & - \\
\hline Horcacitas, Manuel J. & 20000 & - & 1805 & - \\
\hline $\begin{array}{l}\text { Martínez Echarri, Juan } \\
\text { Bautista, comerciante }\end{array}$ & 50000 & 1781 & 1786 & - \\
\hline $\begin{array}{l}\text { Méndez Prieto y } \\
\text { Fernández, Antonio, } \\
\text { regidor de la ciudad de } \\
\text { México, alcalde mayor } \\
\text { Nexapa }\end{array}$ & 40000 & 1776 & 1778 & $\begin{array}{l}\text { Tres fiadores, a plazo } \\
\text { de cuatro años }\end{array}$ \\
\hline $\begin{array}{l}\text { Miramontes, Matías de y } \\
\text { María Antonia de } \\
\text { Umaran }\end{array}$ & 42000 & 1789 & 1796 & - \\
\hline $\begin{array}{l}\text { Picardo y Pacheco, } \\
\text { María Josefa }\end{array}$ & 16000 & - & 1805 & - \\
\hline Quijano, José & 20000 & - & 1805 & - \\
\hline $\begin{array}{l}\text { Quintero, Cayetano, } \\
\text { vecino villa de Altamira, } \\
\text { Nuevo Santander }\end{array}$ & 55000 & 1801 & 1805 & Haciendas \\
\hline $\begin{array}{l}\text { Rábago, condesa de, } \\
\text { María Josefa Peinado y } \\
\text { Valenzuela }\end{array}$ & 45000 & $1790-96$ & 1805 & Haciendas \\
\hline $\begin{array}{l}\text { Romero de Terreros, } \\
\text { Micaela, primogénita del } \\
\text { conde de Regla }\end{array}$ & 60000 & 1782 & 1796 & $\begin{array}{l}\text { Hacienda Tetillas y } \\
\text { bienes no vinculados } \\
\text { del conde de Regla }\end{array}$ \\
\hline $\begin{array}{l}\text { Rul, Digo de, conde de } \\
\text { Rul }\end{array}$ & 60000 & - & 1805 & Haciendas \\
\hline $\begin{array}{l}\text { Sánchez de Espinoza, } \\
\text { José, subrogado de Pedro } \\
\text { de Alcántara, de la Casa } \\
\text { Moneda }\end{array}$ & 67000 & 1786 & 1786 & Hacienda Apam \\
\hline Valle, José Germán del & 25000 & 1784 & 1796 & Ranchos en Cempoala \\
\hline $\begin{array}{l}\text { Vidana, Andrés y Josefa } \\
\text { Gómez de Cedillo, su } \\
\text { testamentaría }\end{array}$ & 26000 & - & 1805 & - \\
\hline
\end{tabular}


Cuadro 3. Préstamos otorgados por la archicofradía de Nuestra SEÑORA DEL Rosario CON FONDOS DE OBRAS PÍAS Y CAPELlANÍAS (CONTINUACIÓN)

\begin{tabular}{|l|c|c|c|l|}
\hline \multicolumn{1}{|c|}{ Prestatarios } & Pesos & Entrega & Vigente & Hipoteca o fiadores \\
\hline Yermo, Gabriel Joaquín & 28000 & 1788 & 1805 & Haciendas \\
\hline \multicolumn{1}{|c|}{ Subtotal } & 646000 & & & \\
\hline Corporaciones & & & & \\
\hline $\begin{array}{l}\text { Ayuntamiento cd. de } \\
\text { México }\end{array}$ & 35000 & & 1805 & \\
\hline Real Hacienda & 32000 & & 1805 & \\
\hline Consulado de México & 90000 & 1794 & 1805 & $\begin{array}{l}\text { Segundo 5 al millar } \\
\text { avería extraordinaria }\end{array}$ \\
\hline Consulado de México & 12000 & 1795 & - & Renta de tabaco \\
\hline Subtotal & 169000 & & & \\
\hline
\end{tabular}

Fuente: Lavrin, 1986b: 259-276 y Valle Pavón, 1997: 289 y 291.

quiebra o muerte de los garantes, quienes tenían que responder por los prestatarios. Gran parte de los fiadores registrados eran vizcaínos y pertenecían al Consulado de México ${ }^{57}$. Algunos miembros de la mesa de gobierno de Aránzazu fungieron como fiadores de los prestatarios, a diferencia de otras hermandades en las que estaba prohibido que desempañaran dicha función ${ }^{58}$. La mayor parte de los depósitos se otorgaban por plazos que fluctuaban entre dos y cinco años, los cuales solían ampliarse cuando los intereses se pagaban con puntualidad $^{59}$. Es muy probable que algunos de los prestatarios y sus garantes realizaran negocios de manera conjunta y recurrieran a la congregación para obtener financiamiento en dinero en un marco institucional que disminuía los riesgos implícitos en las transacciones crediticias.

Los grandes tratantes de ganado que abastecían a la ciudad de México se valieron de la Cofradía de Aránzazu para financiar a quienes los abastecían desde San Miguel el Grande, núcleo de producción agropecuaria estrechamente ligado a los mercados mineros en el que se concentraban las ventas de los animales de la región y del norte de Nueva España ${ }^{60}$. En la villa de San Miguel residía un importante grupo de terratenientes dedicados a la cría y la

57 García Ayluardo, 1985: 60-63; 1985: 44.

58 Estado de los fondos de la Cofradía de Nuestra Señora de Aránzazu, AGN, Cofradías, vol. 6, exp. 4, folios 429-434v.

59 Estado de los fondos de la Cofradía de Nuestra Señora de Aránzazu, AGN, Cofradías, vol. 6, exp. 4, folios 429-434v. García Ayluardo, 1985: 45-46.

60 Quiroz, 2005: 310-321. 
contratación de ganado, gran parte de los cuales eran de origen vizcaíno y estaban ligados por lazos de parentesco ${ }^{61}$. El mercader consular Juan Antonio de Yermo había estrechado sus relaciones con los principales vizcaínos de San Miguel el Grande, al casarse, en 1761, con María Ignacia Díez de Sollano, sobrina del conde de Casa Loja, que era el mayor propietario de tierras en San Miguel el Grande ${ }^{62}$. Yermo, quien había adquirido una hacienda en San Miguel ${ }^{63}$, obtuvo en subasta el contrato del obligado, como se llamaba a la persona que detentaba el monopolio del abasto de carne de la ciudad de México, en los periodos 1771-1773, 1779-1781 y 1784-1786. Los obligados solían ser criadores y tratantes de ganado en mediana escala que arrendaban el suministro de las carnicerías de la capital y de los pueblos adyacentes a grandes criadores y tratantes para satisfacer la enorme cantidad de animales que demandaba la ciudad capital.

En 1773 Gabriel Joaquín de Yermo, que era hermano de Juan Antonio, poseía una casa solariega en San Miguel el Grande y estaba casado con la hermana de Pedro Francisco de la Puente, criador y tratante de ganado que residía en la misma villa ${ }^{64}$ recibió un préstamo de la cofradía de Aránzazu por 16,200 pesos; 9,000 pesos procedían de los fondos de Aránzazu y los restantes 7,200 pesos del Colegio de San Ignacio de Loyola, conocido como Las Vizcaínas, el cual estaba a cargo de la misma congregación. Los fiadores de Gabriel de Yermo fueron su hermano Juan Antonio y Antonio del Villar y Lanzagorta. Los caudales en cuestión acababan de ser redimidos por el mismo Villar y Lanzagorta, quien, muy probablemente, era pariente de Juan María de Lanzagorta, otro de los mayores propietarios de tierras de San Miguel, en donde el primero contrataba ganado para el suministro de la ciudad de México. Antonio del Villar y Lanzagorta había sido rector de la cofradía de Aránzazu en $1770^{65}$.

En 1770 Francisco Díez de Sollano, suegro de Juan Antonio de Yermo y miembro del Consulado de México, fungió como aval de José Mariano de la Canal, vecino de San Miguel el Grande relacionado con el tráfico de ganado, cuyos parientes también poseían grandes extensiones de tierra en dicha juris-

${ }^{61}$ Los Urtuzuástegui, los Lanzagorta, los de la Canal, los de la Puente, entre otros. Véase al respecto el Árbol genealógico y las relaciones de parentesco de los comandantes del Regimiento de la Reina. Sánchez de Tagle, 1982: 86-90.

62 Ibidem: 58, 59, 71, 75, 84.

63 Huerta, 1993: 76.

64 Ibidem: 75-77.

65 Sánchez de Tagle, 1982: 58-60, 75 y 84. García Ayluardo, 1985: 61. Luque Alcaide, 1995: 341. 
Cuadro 4. Informe de la archicofradía de Nuestra Señora de Aránzazu SOBRE OBRAS PÍAS Y CAPELLANÍAS, 1805

\begin{tabular}{|c|c|c|c|}
\hline Prestatarios & Año & Pesos & Fiadores e hipoteca \\
\hline Ayerdi, Juan Antonio & 1804 & 12000 & $\begin{array}{l}\text { José Gabriel Romero, José Mariano y } \\
\text { José Ma. Fagoaga, Gabriel de Yermo y } \\
\text { Manuel Sáenz de Santa María }\end{array}$ \\
\hline Bauza, Francisco & 1798 & 12000 & $\begin{array}{l}\text { Pedro Andrés Ferreyro y Juan Ignacio } \\
\text { Campero [quebraron], Joaquín de las } \\
\text { Piedras, arrienda Hacienda en Apam }\end{array}$ \\
\hline $\begin{array}{l}\text { Gutiérrez de Collado, } \\
\text { José }\end{array}$ & 1801 & 6000 & $\begin{array}{l}\text { Francisco Díaz Noriega y Pedro García } \\
\text { de Aguirre }\end{array}$ \\
\hline Marroquín, Manuel & 1802 & 16200 & $\begin{array}{l}\text { José Martínez de Barenque y Gabriel de } \\
\text { Yermo }\end{array}$ \\
\hline $\begin{array}{l}\text { Negreiros y Soria, José } \\
\text { Ignacio }\end{array}$ & 1800 & 20000 & $\begin{array}{l}\text { Juan Bautista de Fagoaga, difunto, José } \\
\text { Mariano y José María de Fagoaga y } \\
\text { Pablo Vicente de Sola }\end{array}$ \\
\hline $\begin{array}{l}\text { Otaegui, José Antonio y } \\
\text { José Joaquín de Eguía }\end{array}$ & 1786 & 30000 & $\begin{array}{l}\text { José Anastasio y José Pablo de la Rosa, } \\
\text { vecinos del Real Sierra de Pinos }\end{array}$ \\
\hline Palacio, Mateo & 1804 & 20000 & $\begin{array}{l}\text { Hipoteca tres casas y fianza de Pedro de } \\
\text { Zavala y José de Palacio y Lanzagorta }\end{array}$ \\
\hline Pérez de León, Ignacio & 1801 & 4000 & Felipe de Herrera y Mariano López \\
\hline Lozano, Manuel & 1797 & 8000 & Miguel González Calderón \\
\hline Rosas, Joaquín & 1802 & 21172 & $\begin{array}{l}\text { Manuel Francisco de la Brena, Luis de } \\
\text { Escobar, José Palacio Romaña y } \\
\text { Francisco Espinosa }\end{array}$ \\
\hline $\begin{array}{l}\text { Rubio, Nepomuceno, } \\
\text { comerciante Querétaro }\end{array}$ & 1805 & 6000 & $\begin{array}{l}\text { Joaquín Rozas, Pablo de Manchola y } \\
\text { Lorenzo de Yrueta }\end{array}$ \\
\hline $\begin{array}{l}\text { Villa y Torre, Bernardo } \\
\text { José }\end{array}$ & 1793 & 4000 & $\begin{array}{l}\text { Francisco Villa y Torre y José Ruíz de } \\
\text { la Bárcena }\end{array}$ \\
\hline Subtotal & & 159372 & \\
\hline \multicolumn{4}{|l|}{ Corporaciones } \\
\hline Consulado de México & 1802 & 64000 & Hipoteca avería consular \\
\hline Consulado de México & 1795 & 13000 & Hipoteca renta de tabaco \\
\hline Consulado de México & 1798 & 9000 & Hipoteca renta de tabaco \\
\hline Consulado de Veracruz & 1805 & 25000 & Hipoteca ramo del peaje \\
\hline Subtotal & & 111000 & \\
\hline
\end{tabular}

Fuente: Estado de los fondos de la Cofradía de Nuestra Señora de Aránzazu, AGN, Cofradías, vol. 6, exp. 4, folios $429-434 \mathrm{v}$. 
dicción ${ }^{66}$. La enorme influencia que tuvieron los Yermo en la cofradía puede comprobarse tanto por el financiamiento que obtuvieron para sus negocios y los de sus socios, como por el hecho de que Juan Antonio de Yermo fue rector de Aránzazu en 1790-179167, luego de haber sido cónsul del Tribunal mercantil en 1786 y 1787. El sobrino de Juan Antonio y Gabriel Joaquín de Yermo, también llamado Gabriel Joaquín, fue el obligado del abasto de carne en los periodos 1801-1803 y 1803-1805. En 1800 Gabriel Joaquín de Yermo fue aval de Juan María de Lanzagorta, otro miembro de la familia de productores y tratantes de ganado establecidos en San Miguel el Grande ${ }^{68}$.

Juan de Castañiza y Larrea era otro destacado mercader vizcaíno dedicado al tráfico de ganado, quien estaba casado con María Ana González de Agüero y de la Puente, miembro de una de las principales familias de San Miguel el Grande, en donde tenía un almacén. Castañiza fue cónsul del tribunal mercantil en el bienio 1754-1755, fungió como el obligado del suministro de carne a la ciudad de México en 1755-1756, y fue apoderado de distinguidos hacendados y comerciantes de San Miguel, entre los que se destacan Francisco de Urtuzuástegui, José de Landeta, Domingo de Unzaga, Juan Antonio de Arezana, Pedro de Arregui y Pedro Francisco de la Puente ${ }^{69}$. Castañiza brindó su respaldo a algunos de estos individuos para que obtuvieran crédito de la Cofradía de Aránzazu. Tal fue el caso de Antonio de Lanzagorta y Urtuzuástegui, regidor perpetuo de la villa de San Miguel el Grande y comerciante de la ciudad de México, quien, a través de su apoderado y aval, Juan de Castañiza, recibió grandes sumas de dinero a réditos de la cofradía de Aránzazu, entre las décadas de 1740 y $1770^{70}$. Castañiza fue rector de la cofradía de Aránzazu en $1770^{71}$ y prior del Consulado en 1771. Al igual que en el caso de los Yermo, el sobrino y yerno de Castañiza, Antonio de Bassoco continuó con el negocio de la carne. Bassoco fue el rector de la Cofradía de Aránzazu en 1780-1781, obtuvo en remate el abasto de carne en los bienios 1786-1788 y 1796-1797, fue prior del tribunal mercantil de 1795 a 1797, luego de haber sido cónsul en 1781-1782. En las últimas décadas del siglo XVIII, Bassoco realizó grandes contrataciones de ganado en sociedad con Francisco Lanzagorta y Canal, otro de los principales tratantes de ganado de San Miguel el

\footnotetext{
66 Sánchez de Tagle, 1982: 65-70, 84, 86 y 89.

67 Véase el cuadro rectores de Aránzazu, en Luque Alcaide, 1995: 342.

68 Véase el cuadro número 4 Archicofradía de Nuestra Señora de Aránzazu.

69 Huerta, 1993: 76. Sobre las propiedades que tenían algunos de los sujetos que representaba Castañiza, véase Sánchez de Tagle, 1982: 84.

70 García Ayluardo, 1985: 61-62. Luque Alcaide, 1995: 349.

71 Véase el cuadro rectores de Aránzazu, en Luque Alcaide, 1995: 341.
} 
Grande $^{72}$. Es muy probable que Bassoco continuara recibiendo el apoyo financiero de la Cofradía de Nuestra Señora de Aránzazu en los años subsiguientes.

Finalmente, en el cuadro 5 puede verse cómo la asociación piadosa de los vizcaínos destinó una parte importante de sus fondos a los empréstitos para financiar las campañas bélicas de la corona que fueron negociados por el Tribunal del Consulado de México. Asimismo canalizó una suma considerable al cuerpo mercantil de Veracruz para la construcción del camino que iba del puerto jarocho a la villa de Jalapa, muy posiblemente debido a la influencia de Antonio de Bassoco, a quien recurrió el apoderado del consulado de Veracruz a fin de obtener caudales para su proyecto. Bassoco prestó al Consulado de Veracruz para el financiamiento de dicha vía carretera 74,500 pesos de su propia bolsa, mientras que en su papel de tesorero de la Cofradía de San Antonio de Padua consiguió que se destinaran 10,600 pesos y como rector de la Cofradía del Dulce Nombre de Jesús logró que se canalizaran 12,000 pesos más para el mismo objeto ${ }^{73}$.

Por último, la cofradía del Santo Cristo de Burgos concedió préstamos a negociantes montañeses, aunque sus avales no siempre fueron de dicha $n a-$ ción. Como puede verse en el cuadro 5, Juan de Gallareta fue respaldado por el mercader y hacendado vizcaíno Gabriel de Yermo y el montañés Manuel Rubín de Célis, cura de San Cristóbal Ecatepec, que era pariente de otro miembro del Consulado. Al parecer, la congregación de los montañeses también otorgó depósitos a réditos a los tratantes vinculados con el negocio del abasto de carne a la ciudad de México. José Martínez Barenque tuvo como fiadores a los hacendados, tratantes de ganado y miembros del consulado Gabriel Joaquín de Yermo, Pedro de la Puente y Juan Fernando Meoqui, los dos primeros eran originarios del partido de Güemes, en el señorío de Vizcaya y parientes políticos ${ }^{74}$. De acuerdo con las constituciones de la Cofradía del Santo Cristo de Burgos, los miembros de la mesa de gobierno no podían demandar crédito para ellos u otras personas, ni constituirse en fiadores de los prestatarios $^{75}$, probablemente para eliminar las inclinaciones a la connivencia y el favoritismo.

72 Borchart de Moreno, 1984: 76.

73 García Ayluardo, 1985: 40 y 46-47.

74 Pedro Francisco de la Puente era propietario de tierras en San Miguel el Grande y su hermana Josefa de la Puente, se había casado con José de Yermo y Larrazábal, hermano de Juan Antonio de Yermo. Huerta, 1993: 76-77.

75 Salazar, 1990: 63-64. 
Cuadro 5. Informe de la Congregación del Santísimo Cristo de Burgos SOBRE OBRA PÍAS Y CAPELLANÍAS, 1805

\begin{tabular}{|c|c|c|c|}
\hline Prestatarios & Pesos & Año & Hipotecas y fiadores \\
\hline Gallareta, Juan & 60000 & 1790 & $\begin{array}{l}\text { Dr. Manuel Rubín de Celis, cura de } \\
\text { San Cristóbal Ecatepec y Gabriel de } \\
\text { Yermo }\end{array}$ \\
\hline $\begin{array}{l}\text { Gutiérrez del Rivero, José, } \\
\text { marqués de Selva Nevada }\end{array}$ & 12000 & - & s. d. \\
\hline Martínez Barenque, José & 30000 & 1795 & $\begin{array}{l}\text { Gabriel de Yermo, Juan Fernando } \\
\text { Meoqui y Pedro de la Puente, de } \\
\text { Malinalco }\end{array}$ \\
\hline Subtotal & 102000 & & \\
\hline \multicolumn{4}{|l|}{ Corporaciones } \\
\hline Consulado de México & 40000 & 1786 & Avería consular \\
\hline Consulado de México & 6000 & 1793 & $\begin{array}{l}\text { Primer } 5 \text { al millar de avería } \\
\text { extraord. }\end{array}$ \\
\hline Consulado de México & 20000 & 1798 & Renta de tabaco \\
\hline Tribunal de Minería & 8000 & 1794 & Grano por marco acuñado \\
\hline Tribunal de Minería & 50000 & 1796 & Grano por marco acuñado \\
\hline Tribunal de Minería & 16000 & 1804 & Grano por marco acuñado \\
\hline Tribunal de Minería & 48000 & 1805 & Grano por marco acuñado \\
\hline Subtotal & 188000 & & \\
\hline
\end{tabular}

Fuente: Obras Pías y Capellanías de que es Patrona la Ilustre Congregación del Santisimo Cristo de Burgos, 1805, AGN, Cofradías, vol. 6, exp. 7, folios 499-515v. Lavrin, 1985: 15. Valle Pavón, 1997: 287.

De acuerdo con el informe que presentó a la Junta de consolidación la congregación del Cristo de Burgos, en 1805, había otorgado la mayor parte de sus fondos a los tribunales de Minería y del Consulado de México para los empréstitos que negociaron con el propósito de contribuir con las guerras de la monarquía. Estas inversiones pueden explicarse tanto por la participación que tuvieron los mercaderes de México en el Tribunal de Minería, como por la seguridad que ofrecía la hipoteca del derecho sobre la amonedación, los productos de la renta de tabaco y de la avería consular. La cofradía de los montañeses también efectuó un depósito en el cuerpo mercantil de México para apoyar la reconstrucción de los caminos de acceso a la ciudad capital con el propósito de dar empleo a los necesitados que se refugiaron en la gran 
urbe a raíz de los estragos que causó la crisis agrícola de 1786. Presumimos que dicho préstamo fue negociado por Gabriel Gutiérrez de Terán, uno de los miembros vitalicios de la hermandad de los montañeses que fue prior del Consulado en dicho año ${ }^{76}$.

\section{CONSIDERACIONES FINALES}

Los fondos de las capellanías y obras pías que administraban las corporaciones religiosas del arzobispado de México constituyeron una de las principales fuentes de crédito monetario para los mercaderes de la capital del virreinato en el último tercio del siglo XVIII. Destacados miembros del Consulado tenían vínculos estrechos con la jerarquía eclesiástica que administraba las principales corporaciones religiosas, en algunas de las cuales instituían fundaciones piadosas. Los grandes comerciantes también tejían relaciones interpersonales con los administradores y tesoreros de cofradías, colegios, hospitales, recogimientos, hospicios y otros institutos de caridad, en los que establecían obras pías para socorrer a huérfanas, enfermos, viudas y otros necesitados. Estas circunstancias, aunadas a la posibilidad de hipotecar sus propiedades y presentar fiadores para garantizar la recepción de dinero a crédito, transformaron a los mercaderes en los principales beneficiarios del restringido mercado de crédito eclesiástico, junto con los productores agropecuarios. En el sistema de crédito eclesiástico resultaban fundamentales las redes de sociabilidad política y económica.

Las cofradías de laicos fomentaban el culto a devociones particulares, lo que resultaba de gran importancia en el caso de las comunidades nacionales en las que se agrupaban los mercaderes del Consulado de México y otros miembros de la élite. En estas asociaciones se establecían capellanías para asegurar la celebración perpetua de misas por el alma de los fundadores y obras pías destinadas a contribuir con los gastos religiosos y dar caridad a los necesitados, particularmente a los paisanos. Al igual que otras corporaciones eclesiásticas, las hermandades piadosas operaban como intermediarios financieros al captar el dinero acumulado mediante el establecimiento de fundaciones y prestarlo a réditos para su sustento. La gestión de los capitales crediticios de las fundaciones pías por parte de las congregaciones resultaba idónea para los miembros de la élite porque manejaban sus fondos de manera autónoma

76 Obras Pías y Capellanías de que es Patrona la Ilustre Congregación del Santísimo Cristo de Burgos, 1805, AGN, Cofradías, vol. 6, exp. 7, folios 499-515vol. 
y reforzaban las relaciones de confianza en que se basaban sus redes de negocios.

En el último tercio del siglo XVIII, como consecuencia de la activación económica generada por el crecimiento de la producción minera y del establecimiento del comercio libre dentro del imperio, se incrementaron los fondos de las hermandades más acaudaladas, al tiempo que mercaderes, terratenientes y destacados funcionarios de la administración eclesiástica y civil erigían nuevas asociaciones piadosas. La institución de capellanías y obras pías, así como la oferta de los fondos crediticios con los que se establecían reflejaban el dinamismo de la economía que fortalecía los incipientes mercados de crédito eclesiástico. En trabajos posteriores convendría investigar quiénes fueron los fundadores de las nuevas capellanías y obras pías, a fin de conocer a los principales beneficiarios del crecimiento económico que se produjo en esos años.

Las mesas de gobierno de las cofradías más acaudaladas estaban integradas, mayoritariamente, por prominentes miembros del Consulado de México, algunos de los cuales participaban en los consejos de dos o tres hermandades de manera simultánea. Estos personajes tenían gran poder económico y político porque decidían a quienes otorgar los fondos crediticios que administraban. En esta forma los mercaderes reforzaban el tejido de sus redes de negocios.

Al analizar el crédito que otorgaron cuatro de las asociaciones piadosas más ricas de la ciudad de México, encontramos que en todas se practicaba la solidaridad comunitaria, aun cuando tenían criterios diferentes para canalizar sus fondos. Las archicofradías del Santísimo Sacramento y de Nuestra Señora del Rosario concedieron dinero a réditos, principalmente, a grandes empresarios agropecuarios que hipotecaban sus propiedades en garantía. En cambio, las cofradías del Santo Cristo de Burgos y de Nuestra Señora de Aránzazu, en las que se agrupaban los mercaderes consulares de origen montañés y vizcaíno, destinaron sus fondos a negociantes de las respectivas naciones con el respaldo de fiadores que no necesariamente pertenecían a la misma hermandad. El crédito que otorgaron las cofradías en las que predominaban los miembros del cuerpo mercantil se basaba en relaciones de confianza, por lo que era garantizado por fiadores. El acceso al crédito se basaba, en gran medida, en relaciones interpersonales, así como en la exigencia de garantías hipotecarias y fiadores, esto explica que la mayor parte de los capitales piadosos de las hermandades se destinaban a productores agropecuarios y mercaderes. En el caso de la cofradía de Aránzazu, vimos los vínculos que había entre los miembros de la mesa de gobierno y los sujetos que demandaban crédito. En el futuro sería conveniente conocer a los personajes que integraban 
los consejos de las cofradías, así como las relaciones que tenían con los prestatarios y sus fiadores con el propósito de identificar la conformación de redes sociales. Todo parece indicar que ciertos mercaderes se valieron de las cofradías de Aránzazu y, en menor medida, de la del Cristo de Burgos para otorgar financiamiento a sus socios en un marco institucional que disminuía los riesgos implícitos en las transacciones crediticias. En este caso se encontraban los grandes comerciantes de ganado que se encargaban del abasto de la ciudad de México, los Yermo, los Diéz de Soyano y los Castañiza-Bassoco que formaban redes con los Lanzagorta y otros criadores y tratantes de ganado vecinos de San Miguel el Grande. Estos se otorgaban fianzas mutuamente y, en algunos casos, los fondos redimidos se prestaban a individuos relacionados con quienes los habían devuelto, de modo que los caudales quedaban dentro del mismo círculo de relaciones.

Las congregaciones que examinamos también colocaron dinero a réditos en los tribunales del Consulado y Minería, corporaciones que operaron como intermediarios financieros de la real Hacienda para apoyar las guerras contra las potencias europeas de fines del siglo XVIII y principios del siglo XIX. Dichas inversiones se realizaron tanto por la influencia que tenían los mercaderes en las mesas de gobierno de las cofradías en cuestión, como por el interés en apuntalar a elementos de sus redes que se encontraban a la cabeza de los tribunales mencionados. Llama la atención las enormes sumas que canalizaron a dicho objeto la congregación del Santo Cristo de Burgos y la archicofradía del Santísimo Sacramento, las cuales pueden explicarse, tanto por la lealtad que se profesaba a la monarquía, como por la confianza que se tenía en las corporaciones de mercaderes y mineros. La archicofradía del Santísimo Sacramento y la cofradía de Aránzazu, además, prestaron cantidades muy considerables al Consulado de Veracruz para la construcción del camino carretero que iba del puerto de Veracruz a la villa de Jalapa. Al parecer, dichas inversiones se efectuaron por influencia de Antonio de Bassoco, quien estaba interesado en la reconstrucción de dicha vía carretera.

\section{BiBLIOGRAFÍA}

Abad y Queipo, Manuel, "Escrito presentado a don Manuel Sixto Espinosa del Consejo de Estado y Director Único del Príncipe de la Paz en asuntos de real Hacienda dirigido a fin de que se suspendiese en las Américas la real cédula del 26 de diciembre de 1804, sobre enajenación de bienes raíces y cobro de capitales píos para la Consolidación de vales reales", Crédito Público, UNAM/Miguel Ángel Porrúa, 1986: 100-117 
Bauer, A. J., "La iglesia en la economía de América Latina siglos XVI al XIX”, A. J. Bauer, La iglesia en la economía de América Latina siglos XVI al XIX, México, INAH, 1986: 13-57.

Bazarte, Alicia, Las cofradías de españoles en la ciudad de México (1526-1864), México, UAM/Azcapotzalco, 1989.

Borchart de Moreno, Christiana Renate, Los mercaderes y el capitalismo en México (1759-1778), México, FCE, 1984.

Brading, David, Mineros y comerciantes en el México borbónico (1763-1810), México, FCE, 1975.

Carbajal López, David, "La reforma de las cofradías novohispana en el Consejo de Indias 1767-1820", Revista Complutense de Historia de América, 38 (Madrid, 2012): 79-101.

Couturier, Edith B., "Una viuda aristócrata en la Nueva España del siglo XVIII: la condesa de Miravalle", Historia Mexicana, XLI/3 (México, enero-marzo 1992): 327-357.

Fernández García, Ana María, "El retablo de la Congregación de Nuestra Señora de Covadonga de México", Homenaje a Juan Uría Riu, Oviedo, Servicio de Publicaciones de la Universidad de Oviedo, 1997, vol. II: 777-796.

Florescano, Enrique y Castillo, Fernando (comps.), Controversia sobre la libertad de comercio en Nueva España 1776-1818, México, Instituto Mexicano de Comercio Exterior, 1975, 2 vols.

García Ayluardo, Clara, "Sociedad, crédito y cofradía en la Nueva España. El caso de Nuestra Señora de Aránzazu”, Historias, 3 (México, enero-marzo 1983): 53-68.

García Ayluardo, Clara, "El comerciante y el crédito durante la época borbónica en la Nueva España", Leonor Ludlow y Carlos Marichal (eds.), Banca y poder en México (1800-1925), México, Editorial Grijalbo, 1986: 27-50.

García Ayluardo, Clara, "El privilegio de pertenecer: las comunidades de fieles y la crisis de la monarquía católica", Beatriz Rojas (coord.), Cuerpo político y pluralidad de derechos. Los privilegios de las corporaciones novohispanas, México, CIDE/Instituto Mora, 2007: 85-128.

García Ayluardo, Clara, "Re-formar la Iglesia novohispana", Clara García Ayluardo (coord.), Las Reformas Borbónicas, 1750-1808, México, CIDE/INEHRM/CONACULTA/FCE, 2010: 225-287.

Greenow, Linda, Credit and Socioeconomic Change in Colonial Mexico: Loans and Mortages in Guadalajara, 1720-1820, Boulder, Wesview Dellplain, 1983.

Hilferding, Rudolf, El capital financiero, Madrid, Editorial Técnos, 1971.

Kicza, John E., Empresarios coloniales. Familias y negocios en la ciudad de México durante los Borbones, México, FCE, 1986. 
Lavrin, Asunción, "La Congregación de San Pedro. Una cofradía urbana del México Colonial. 1604-1730", Historia Mexicana, $29 / 4$ (México, abril-junio de 1980): 562-601.

Lavrin, Asunción, "El capital eclesiástico y las élites en Nueva España", Mexican Studies/Estudios Mexicanos, 1/1 (Irvine, 1985): 1-28.

Lavrin, Asunción, "Los conventos de monjas en la Nueva España", Arnold J. Bauer, La iglesia en la economía de América Latina siglos XVI al XIX, México, INAH, 1986a: 193-222.

Lavrin, Asunción, "Mundos en contraste: cofradías rurales y urbanas en México a fines del siglo XVIII", Arnold J. Bauer, La iglesia en la economía de América Latina siglos XVI al XIX, México, Instituto Nacional de Antropología e Historia, 1986b: 235-276.

Le Goff, Jacques, La Bolsa y la vida. Economía y religión en la Edad Media, Barcelona, Gedisa Editorial, 1996.

Luque Alcaide, Elisa, La cofradía de Aránzazu de México (1681-1799), Pamplona, Ediciones Eunate, 1995.

Manzano Manzano, Juan (estudio preliminar), Recopilación de Leyes de los Reynos de Indias, pról. Ramón Menéndez y Pidal, Madrid, Cultura Hispánica, 1973 [1681].

Martínez López-Cano, Pilar y Valle Pavón, Guillermina del, "Estudios sobre el crédito colonial: problemas, avances y perspectivas", Pilar Martínez López-Cano y Guillermina del Valle Pavón, El crédito en Nueva España, México, Instituto Mora/ COLMICH/COLMEX/UNAM, 1998: 13-32.

Moreno de los Arcos, Roberto, "Las instituciones de la industria minera novohispana”, Miguel León Portilla et al., La minería en México; estudios sobre su desarrollo histórico, México, IIH-UNAM, 1978.

Pérez Herrero, Pedro, Plata y libranzas. La articulación comercial del México borbónico, México, COLMEX, 1988.

Salazar, Nuria, La capilla del Santo Cristo de Burgos en el ex Convento de San Francisco, México, INAH/Secretaría General de Desarrollo Social- Departamento del Distrito Federal, 1990.

Sánchez de Tagle, Esteban, Por un Regimiento, el régimen: política y sociedad. La formación del Regimiento de Dragones de la Reina en San Miguel el Grande, 1774, México, INAH, 1982.

Sánchez Santiró, Ernest, "La minería novohispana a fines del periodo colonial. Una evaluación historiográfica", Estudios de Historia Novohispana, 27 (México, julio-diciembre 2002): 123-164. 
Sugawara, Masae, La deuda pública de España y la economía novohispana, México, INAH, 1976.

Valle Pavón, Guillermina del, "Las corporaciones religiosas en los empréstitos negociados por el Consulado de México a fines del siglo XVIII", Pilar Martínez López-Cano (coord.), Iglesia, Estado y Economía siglos XVI a XIX, México, UNAM/Instituto Mora, 1995: 225-240.

Valle Pavón, Guillermina del, "Apertura comercial del imperio y reconstitución de facciones en el consulado de México: el conflicto electoral de 1787", Guillermina del Valle Pavón (coord.), Mercaderes, comercio y consulados de Nueva España en el siglo XVIII, México, Instituto Mora, 2003: 259-290.

Valle Pavón, Guillermina del, "Los excedentes del ramo de alcabalas. Habilitación de la minería y defensa del monopolio de los mercaderes de México en el siglo XVIII”, Historia Mexicana, LVI/2 (223) (México, enero-marzo 2007): 969-1016.

Valle Pavón, Guillermina del, "Antonio de Bassoco, empresario del consulado de México en una época de cambios", Leonor Ludlow (coord.), 200 emprendedores mexicanos. La construcción de la nación, México, Lid Editorial, 2010a, vol. I: 53-58.

Valle Pavón, Guillermina del, "Comercialización de cacao de Guayaquil por los mercaderes del Consulado de México en la segunda mitad del siglo XVIII", Mexican Studies/Estudios Mexicanos, 26/2 (Irvine, 2010b): 181-206.

Valle Pavón, Guillermina del, "Respaldo financiero de Nueva España para la guerra contra Gran Bretaña 1779-1783. La intermediación financiera del Consulado de México", Ernest Sánchez Santiró y Ángelo Alves Carrara (coords.), Guerra y fiscalidad en la Iberoamérica colonial (siglos XVII-XIX), México, Instituto Mora, 2012: 143-166.

Vázquez de Prada, Valentín, "Mecanismos crediticios en la ciudad de México en el siglo XVI", Leonor Ludlow y Jorge Silva Riquer (coords.), Los negocios y las ganancias: de la colonia al México moderno, México, Instituto Mora/ UNAM, 1993: 17-35.

Wobeser, Gisela von, "La inquisición como institución crediticia en el siglo XVIII", Historia mexicana, XXXIX/4 (156) (México, abril-junio 1990): 849-879.

Wobeser, Gisela von, El crédito eclesiástico en la Nueva España. Siglo XVIII, México, UNAM, 1994.

Wobeser, Gisela von, Dominación colonial. La consolidación de vales reales en Nueva España 1804-1809, México, UNAM 2003.

Wobeser, Gisela von, Vida eterna y preocupaciones terrenales. Las capellanías de misas en la Nueva España, 1600-1821, México, UNAM, 2005.

Fecha de recepción: 1 de febrero de 2013.

Fecha de aceptación: 3 de abril de 2013. 


\section{Credit Functions of the Brotherhoods and the Businesses of the Merchants of the Mexico City Consulate in the Late 18th and Early $19^{\text {th }}$ Centuries}

This study analyzes the way in which the merchants of the Mexico City Consulate took advantage of the guilds and other religious corporations' credit in the last decades of the $18^{\text {th }}$ century, when the ecclesiastical credit market was revitalized as a result of the reactivation of New Spain's economy. The afore-mentioned merchants were among the principal founders of pious works and were the main beneficiaries of the pious funds that were administered by the religious corporations, as is shown upon studying four of the wealthiest pious brotherhoods.

KEY WORDS: ecclesiastical credit; brotherhoods; merchants; consulates; social networks. 